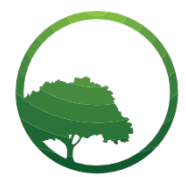

Research in Business \& Social Science

IJRBS VOL 8 NO 6 ISSN: 2147-4478

Business \& Social Science IJRBS

Available online at www.ssbfnet.com Journal homepage: https://www.ssbfnet.com/ojs/index.php/ijrbs

\title{
Impact of cotton textile sector trends in Cameroon
}

\author{
Nguepi Tsafack Elvis ${ }^{{ }^{*}}$ \\ ${ }^{a}$ School of Economics and Management, Zhejiang Sci-Tech University, Hangzhou, China
}

Crossref

\begin{tabular}{l} 
A R T I C L E I N F O \\
\hline Article history: \\
Received 07 July 19 \\
Received in revised form 22 July 19 \\
Accepted 08 August 19 \\
\hline Keywords: \\
Cameroon \\
Cotton Sector \\
Textile Production \\
Agricultural Policies \\
Price \\
JEL Classification: \\
L19
\end{tabular}

\begin{abstract}
A B S T R A C T
This study attempts to clarify and evaluate the factors that impact on cotton sector production in Cameroon and differentiate producers behavior. A description of producers .behaviour is made in order to identify their main characteristics, which should shed light on the relationships between cotton textile production, the main producers ' characteristics price and non-price variables. An inventory of ongoing sectoral agricultural policies is presented and suggestions are made for formulating alternative policies. The next section presents both a review of agricultural policies and the cotton sector in Cameroon. The third and fourth sections are literature review and cotton belt while the fifth presents the methodology. Discussion and interpretation of the empirical findings is followed by the conclusion and policy recommendations.
\end{abstract}

\section{Introduction}

The cotton sector of Cameroon is unique among its West and Central African peers in that no major structural reforms have been implemented over the last 40 years. SODECOTON, the national cotton company, remains under the control of the Government of Cameroon.s (GoC). It has nevertheless expanded its operations and is able to operate without external support, in spite of the strong appreciation of its currency (the CFA Franc) against the US dollar in recent years. Cameroon has suffered an ongoing economic crisis since the second half of the 1980s Food and Agriculture Organization of the United Nations (FAO). Among the most cited causes of this crisis are the degradation of the terms of trade, resulting from a fall in the prices of the major export products, the overvaluation of the CFA franc against the US dollar and certain internal distortions (Bland ford 1995; Tybout 1996).

Despite of strong sales over the past decade and a prudent pricing policy, the sustainability of the cotton sector is presently threatened by the combined effects of low prices and the appreciation of the local currency. SODECOTON is now facing a difficult dilemma: Without cash reserves to maintain producer prices at their current level, the company fears that production levels will drop drastically.

The impact of the crisis can be appreciated on both aggregate and sectoral levels. On the aggregate level, there was a decline in gross domestic product (GDP) by an average of 4 per cent per annum between1992/93, a growing deficit in the balance of payments and an increase in both internal and external debts.

On the sectoral level, the crisis appears to have spread in a different manner .

\footnotetext{
* Corresponding author. ORCID ID: 0000-0003-2282-6607

Peer review under responsibility of Bussecon International Academy.

(C) 2019 Bussecon International. Hosting by SSBFNET- Center for Strategic Studies in Business \& Finance. All rights reserved.

https://doi.org/10.20525/ijrbs.v8i6.567
} 
Table 1: Change in GDP by Activity Groups in Cameroon (billions of CFA francs)

\begin{tabular}{llllll}
\hline & $\mathbf{1 9 8 9 / 9 0}$ & $\mathbf{1 9 9 0 / 9 1}$ & $\mathbf{1 9 9 1 / 9 2}$ & $\mathbf{1 9 9 2 / 9 3}$ & $\mathbf{1 9 9 3 / 9 4}$ \\
\hline Primary & 804.5 & 810.3 & 858.7 & 860.6 & $1,031.5$ \\
\hline Secondary & 945.7 & 909.1 & 741.1 & 719.7 & 757.4 \\
\hline Tertiary & $1,117.1$ & $1,181.5$ & $1,158.3$ & $1,148.8$ & $1,299.8$ \\
\hline Total & $2,927.3$ & $2,900.9$ & $2,758.1$ & $2,728.5$ & $3,088.7$ \\
\hline Variation (\%) & ND & -0.9 & -5.0 & -1.1 & 13.2 \\
\hline Source: MINEFI/DSCN1996 & & & &
\end{tabular}

Table1 shows the cotton agricultural sector has outperformed the industrial sector. However , behind this general performance by agriculture lie great disparities among the main agricultural exports, with cocoa and coffee outputs continuously falling since 1994 while that of cotton was increasing. As presented in table 2.

Table 2: Change in Main Export Crops (thousands of tons) and Their Prices (CFA francs $/ \mathrm{Kg}$ )

\begin{tabular}{llllll}
\hline & $\mathbf{1 9 8 9} / \mathbf{9 0}$ & $\mathbf{1 9 9 0} / \mathbf{9 1}$ & $\mathbf{1 9 9 1 / 9 2}$ & $\mathbf{1 9 9 2 / 9 3}$ & $\mathbf{1 9 9 3 / 9 4}$ \\
\hline Arabica coffee & 11,3 & 13.1 & 12.8 & 10.6 & 9.9 \\
& $(483)$ & $(250)$ & $(238)$ & $7200)$ & $(196)$ \\
\hline Robusta coffee & 81,9 & 80.5 & 78.0 & 77.5 & 75,0 \\
& $(463)$ & $(175)$ & $(148)$ & 89.0 & $(134)$ \\
\hline Cocoa & 120.0 & 99.0 & 95.0 & $(182)$ & 85.0 \\
& $(443)$ & $(250)$ & $110)$ & 125.7 & $(179)$ \\
\hline Cotton & 103.9 & 113.2 & $(90)$ & $(86)$ & $(86.5$ \\
& $(142)$ & $(95)$ & & & $(80)$ \\
\hline
\end{tabular}

Note: Prices in parenthesis.

Source: FAO 1995, MINEFI/DSCN 1996, Tshibaka 1997.

At the level of the cotton sector, some disparities are also found. In terms of the trend of cotton production, sustained aggregate growth is only derived from the compensation between a decrease in production of some farmers and the rise by others. In fact, peasant profiles are not comparable since production is increasing for some farmers and either constant or fluctuating for others. Since the purchase price of cotton is the same for all farmers, fluctuations in production as much as differences among farmers seem to indicate that exist factors other than price that significantly affect producer behavior.

\section{The Cotton Sector in the Agricultural Policies of Cameroon}

From the independence in 1960 up to 2018, Cameroon has experienced two main agricultural policies, namely state intervention to 1987 and liberalization thereafter. These policies are reviewed before the cotton sector is analyzed in more detail.

From 1987 to 1993, the Cameroonian economy suffered a sharp drop in export earnings because of the steady decline in the price of leading exports (oil, coffee, cocoa and Cotton) and a fall in the GDP. Between 1985 and 1995, GDP reduced drastically by 6.3 percent per year. This resulted in an imbalance of macroeconomic accounts and ,more importantly, a deficit in public finances .During 19871988 , the state.s main instrument for managing exports sectors, ONCPB recorded a deficit of nearly 30 billion XAF. Because of the weaknesses of the state intervention in 1988 and after a series of successive of macroeconomic stabilization programs and structural reforms.

The Cameroon government decided to implement measures that reflected Structural Adjustment Programs (SAPs) agreed with the Bretton Woods Institutions. The economic policy process focused on redefining the development strategy, especially the role of the state in the economic sphere. This gave rise to a liberalized environment, characterized by non-tariff barriers being gradually reduced, restructuring or privatizing /liquidating most production and commercialization enterprises, deregulating prices, and making actors, including professional and inter professional organizations, accountable. In this particular context, a national seminar on cooperatives was held in Yaoundé in 1988 during which the crisis of the system was acknowledged and the groundwork for cooperative reform was laid out. This brought about in the enactment of the Law on Freedom of Association in 1990. This law was then supplemented in 1992 by the law on common initiative groups and cooperatives.

From (1990 - 2018 ), the guidelines of this policy focused on implementing deregulation and privatization measures to streamline resources, finding more efficient management practices and privatizing the capital management of parastatal enterprises. The operating mode was to empower more farmers to diversify agricultural production, enhance production potential and existing market opportunities and protect domestic production. 


\section{The Cotton Sector in Cameroon}

Using figures from the FAO, Cameroon's cotton exports in 2018 increased by $23 \%$ of gross domestic product and employs $62 \%$ of the population, making the commodity the only agricultural export product in the country to have recorded such an improvement over the year (see Figure 1). The cotton is quite significant in the domestic economy. It is not only the main trading crop in its growing area but also a raw material for downstream industries. The wide range of activities linked to its cultivation can be grouped into three homogeneous categories: cotton cultivation, cotton processing and textile production, which will now be considered in turn.

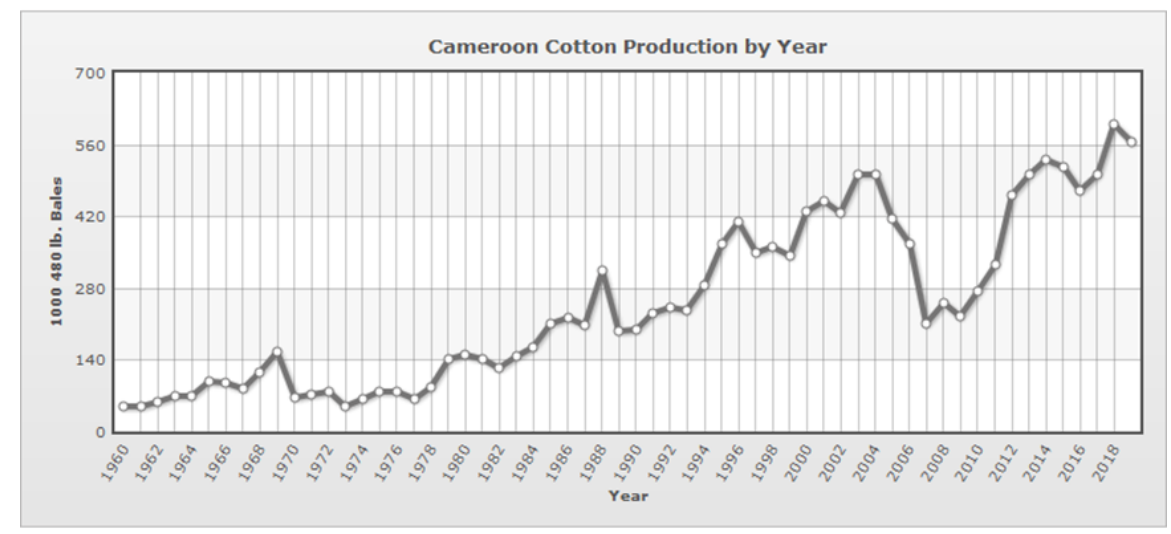

Source: Cameroon CM: Nominal Effective Exchange Rate Index: From INS, 2019

Figure 1: Cameroon Cotton Production from 1960-2018

\section{Review of Cotton Agricultural Policies and Textile Production}

\section{Review of Cotton Agricultural Policies}

State interventions in the agricultural sector were both indirect and direct .In terms of indirect interventions, these can be seen as the continuation of French and British colonial through marketing boards, which had a monopoly over the agricultural export trade. Through the National Produce Marketing Board (NPMB), this strategy allowed the government to retain a fraction of the nominal world market prices of export crops to finance public consumption and investment needs. Nevertheless, this policy was coupled with guidance of farmers by providing subsidized inputs through parastatals such as SODECOTON and SOCAPLAM.

Direct intervention involved state corporations controlling activities formerly carried out by the private sector. The government sought to increase agricultural productivity through the establishment of a modern sector involving the expansion of plantation farming by some organizations.

The second phase started since 2005 with adoption of the structural adjustment programme (SAP) whose main objectives were to redefine the role of government and reduce its interventions in the economy. In the agricultural sector, many functions formerly handled by corporations under state control were privatized. Even under this new policy, however, the cotton sector is still controlled by a parastatal while other crops such as coffee and cocoa have been liberalized. In fact, the introduction of an export tax in 1994 and the withdrawal of the government in fixing purchase prices to farmers are the only major changes in the cotton sector.

\section{Overview of the Cotton Sector in Cameroon}

Cotton production began in Cameroon in the early 1950s, at the end of the colonial era. It was under the control of CFDT (Compagnie Française de Développement des Fibres Textiles), a French parastatal which was created a decade earlier to supply the French textile industry with fiber.

In 1974, a decade after independence, SODECOTON was created as a mixed-economy company (société anonyme d.économie mixte), with the majority of capital belonging to the Government and a minority to CFDT (later renamed as DAGRIS). The company was granted a monopoly for developing cotton in the Northern part of Cameroon, purchasing seed cotton from farmers, as well as processing and marketing lint cotton. In return, the company assumed an obligation to buy all seed cotton produced anywhere in Cameroon at a fixed price.

Similar to CMDT ( Compagnie Malienne pour le Développement des Fibres Textiles ) in Mali, SODECOTON.s mandate was not restricted to cotton, and included a more general rural development mandate as well.

Immediately after its creation SODECOTON intensified the country.s cotton production, which was fully extensive up to that time, without any fertilizer application. From 1974 until 1988, GoC and SODECOTON supported production through public investment 
initiatives, input subsidies, and favorable producer prices. This policy successfully expanded cotton production but resulted in huge deficits for SODECOTON (more than 60 billion FCFA of cumulative deficit,) which threatened the very existence of the company. In 1987, the Office National Camerounais des Produits de Base (ONPCB), a parastatal in charge of financing subsidies to the agricultural export sectors, went bankrupt after posting more than 20 billion FCFA in losses in 1986. With the assistance of donors (in particular Agence Française de Développement - AFD) SODECOTON and GoC, agreed upon a safeguard strategy in 1988. The strategy included an adjustment of the producer prices, an increase in prices for agricultural inputs, the development of a research program devoted to reducing production costs, and a drastic reduction in the extension costs borne by SODECOTON.

The cotton sector, mostly grown in northern Cameroon and Chad, is doing relatively poorly. Given that producers receive low payments, the most important indicators are declining, including harvested area, production, the actual number of producers and yields. In Cameroon, for example, the areas used for cotton production have been reduced by 43 percent, going from 231993 hectares in 2005 to 133000 hectares in 2008. Over the same period, the number of producers has dropped from 300000 to 218000 , a decrease of nearly 27 percent.

\section{Key Macro-Economic Factors Influencing the Sector}

As in all FCFA-zone cotton-producing countries, the two main macro-economic factors influencing the Cameroon cotton sector are the decline in world prices and the appreciation of CFA Franc against the dollar since 2007 as shown in the figure 2 below, the nominal and rate exchange between 2007 and 2018

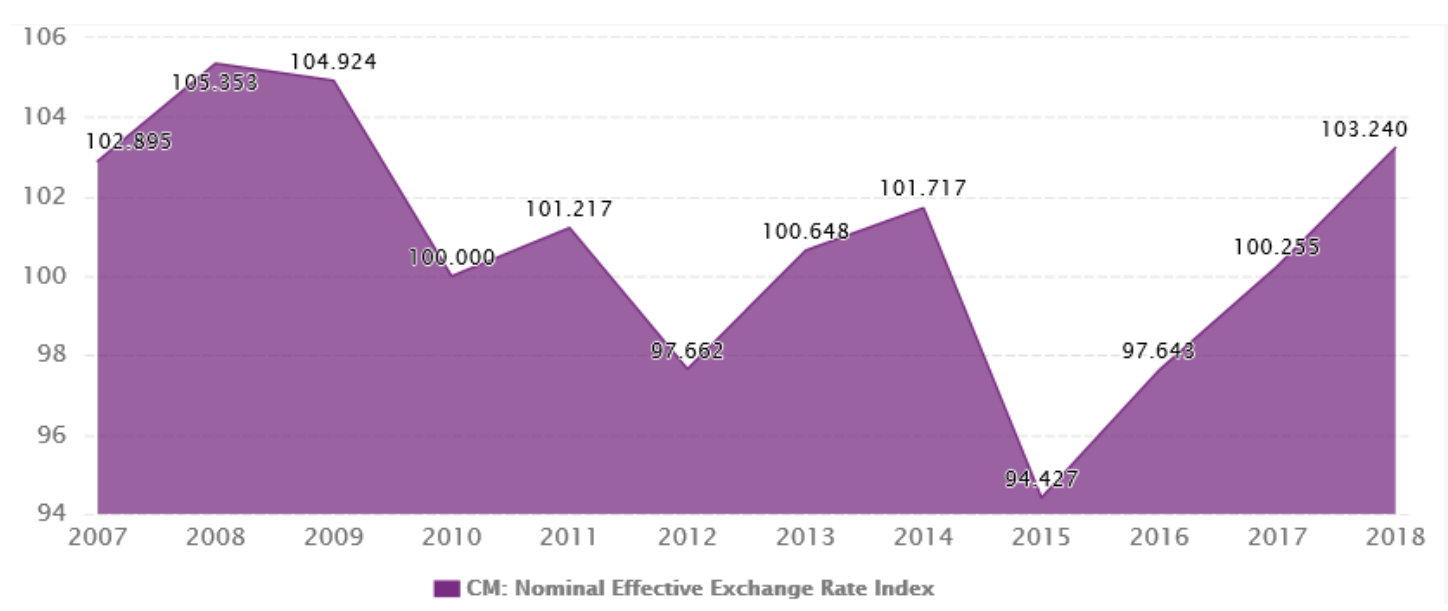

Source: Cameroon CM: Nominal Effective Exchange Rate Index: From INS., 2019

Figure 2: Nominal and real exchange rate index in Cameroon From 2007-2018

\section{Cultivation of Cotton and Trends}

The cotton-cultivation areas in Cameroon are concentrated in the North and far North provinces. In these areas, the farming system is characterized by mixed crop cultivation and growing breeding integration. Mixed crop cultivation entails judicious selection in the use of land while growing breeding integration gives rise to conflicts between farmers and breeders since the extensive nature of the pastoral system encroaches on cultivable land. These conflicts can be exacerbated by dense populations, which increase pressure on land disputes. Since populations density and housing are linked high density means high demand for housing and consequently for land. s such ,population density variably affects the land available for agriculture since it varies from one cultivating area to another.

On the other hand, rainfall is regular in one cultivating area and not in the other. As such, one can assume that the cultivating area differentiates farmers. behavior. Production also depends on the ploughing system adopted, the two categories being the harnessed ploughing system (HPS) and a manual ploughing system (MPS). With labor being mainly family-based, the size of the area cultivated is related to family size. Lastly, cotton production is still handled by SODECOTON.

SODECOTON provides both information and agricultural inputs. Farmers are given guidance in using improved seed and phytosanitary products .On the inputs side, the policy is to provide all inputs on credit. Raymond (1998) notes that this provision of inputs at the right time and on credit is a factor that accounts for the success of cotton in the growing zone. In general, cotton is sold on the farm and SODECTON ensures its transport to the factories. 
World cotton production and consumption have risen from 7 million metric tons in 1950/51 to 26 million tons today; the average annual increase has been nearly 300,000 tons. When looked at in the long run, and especially with a trend line imposed, world cotton production seems to be climbing steadily. However, there have been distinct periods of plateaus and jumps to new levels.

World cotton production rose to 26 million tons in the current season ending in July, and production is expected to remain about as high in the season that will start in August 2018. World cotton use is forecast to climb to nearly 27 million tons in 2018/19, which will finally mark a full recovery to the level achieved prior to the recession a decade ago. World trade in cotton is forecast to climb to 9 million tons, the highest in several seasons.

India, China, and the United States account for two-thirds of world cotton production, while China, India and Pakistan account for a similar percentage of world cotton consumption.

Among Sub-Sharan African producing countries, Mali (304,000 tons), Burkina Faso (258,000 tons), Benin (183,000 tons), Cote d.Ivoire (170,000 tons) and Cameroon (116,000 tons) are the largest in 2017/18. The levels of production in 2017/18 were either record or nearly record high in each of the five countries and represented a return to production levels recorded in the mid-2000s.

However, the rise in production since 1990 represented increased area devoted to cotton, not an improvement in yields. Yields in Sub-Saharan Africa fell from 375 kilograms per hectare in 2004/05 to about 300 kilograms currently. Of the five largest producers in Africa, only Cameroon maintained yields in the pre-recession and post-recession eras; the yield in Cameroon was about 500 kilograms per hectare in both periods. India, China, and the United States account for two-thirds of world cotton production, while China, India and Pakistan account for a similar percentage of world cotton consumption. As presented in figures ( $3 \& 4)$

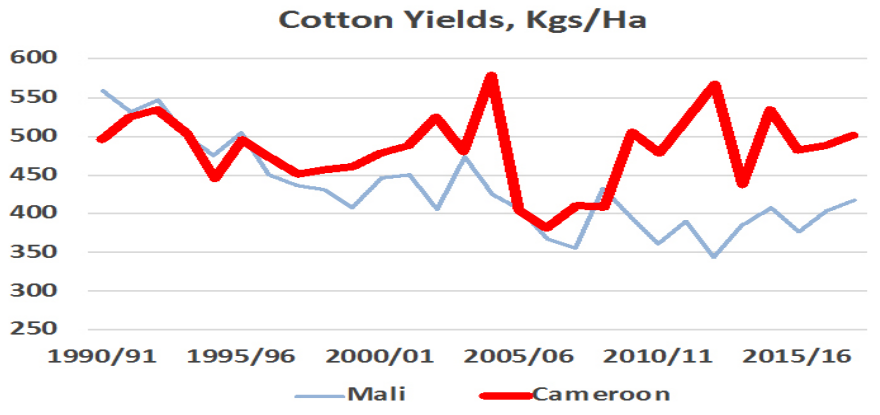

Source: Townsend, 2018

Figure 3: Cotton Yields Cameroon- Mali from 1990-2016

Yields are a function of the quantity, quality and correct application of fertilizer and other inputs such as insecticides and planting seeds. In a natural setting, such as a forest or pasture where nothing is harvested by humans, the environment will reach a natural balance.

Cameroon is the only large Sub-Saharan African producer that has been able to supply farmers with adequate amounts of fertilizer in a timely manner each season so as to be able to preserve soil fertility and maintain cotton yields. In other countries, soil fertility is declining as input availability to farmers has diminished.

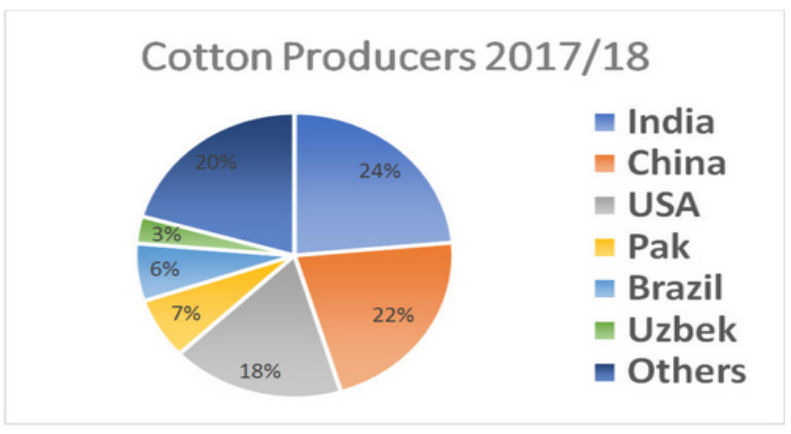

Source: Townsend, 2018

Figure 4: Cotton Analytics from 2017 to 2018 


\section{Cotton Processing}

The study on the analysis of the cotton textile sector in Cameroon, tells us that only $2 \%$ of cotton produced in Cameroon is processed locally. As for the transformation of the cotton fiber, Paul Biya.s (Cameroon.s president) country is badly off. There is only the Cotton Industry Cameroon (CICAM) which ensures the local processing of cotton. The company is currently piloting a 5.5 billion FCFA investment program.

This program aims at strengthening the capacity of CICAM to absorb the national production of cotton. According to the statistics, the Cameroon Industrial Cotton Producer transforms 1,500 tons of fibers each year. Its production comes down to 300 tons of sponge, 1,500 tons of threads and 8,000 km of unbleached fabrics. Cameroon does not have an integrated cotton-textile-clothing sector.

These industrial shortcomings generate economic losses. It appears that the Cameroonian economy is unable to capture the benefits of value-added. Said value is multiplied by 12 between the raw cotton and a made-up garment. Cotton cultivation was introduced in Cameroon in 1950. To develop the sector, the Cameroonian State created the Cameroon Cotton Development Corporation (SODECOTON).

SODECOTON is in charge of all cotton processing activities. Cotton fibre and seed are initially processed by factories, which annual capacity is 130,000 tonnesof fibre. Data on production show that this capacity is poorly used. As regards fiber, an annual average of 15 percent is sold to domestic industries while 85 percent is sold abroad.

Three oil factories, with a capacity of 60,000 tones, triturate the seed obtained from the initial processing. These factories produce crude cotton oil as well as expellers. Which are sold to husbandry as animal feed. A proportion of crude cotton oil is used to provision soap and paint manufacturers and part is refined to produce edible cotton oil.

\section{Cotton Textile production in Cameroon}

Production here refers to cloth, household linen and threads, obtained through spinning, dyeing, weaving, pressing, finishing and other processes. The various herein can be grouped into three homogeneous categories: (i) tissue production, (ii) hosiery and (iii) dressmaking.

Tissue production involves using cotton fibre in producing cloth through spinning, weaving and tincturing. This is done by a parastatal, CICAM, which was created in since 1965 with a view to reduce importation and promote use of local raw materials processed locally. Since the quality of Cameroonian cotton is found to be superior to what CICAM needs, its domestic use is less than 15 percent per annual. However, with its two factories in Garoua and Douala, CICAM remains the largest producer in Cameroon and the central African sub-region (Kloboukoff et al 1995 ). The factory at Garoua has the monopoly of carrying out weaving and spinning for production cotton ecru and yarn . Part of this product is export-oriented while the balance goes to produce tissue cloth in Douala factory, which also had a monopoly until 1986 when an Indian firm set up in competition.

SODECOTON has kept producer prices stable between CFAfr150 (31 US cents) and CFAfr200 since 1995. The regulated price acted as an incentive for farmers to cultivate cotton while the international price remained relatively stable and in line with other cash crops. However, since 2005 the price of other cash crops has risen faster than cotton, while fertilizer prices increased substantially and farmers have been prevented from selling their cotton abroad. While the CFA franc value of cotton increased by $250 \%$ on the international market between the first quarter of 2009 and the first quarter of 2011, the regulated price in Cameroon increased by less than $30 \%$. As a result, many farmers have started to cultivate other crops or have shifted into the black market. Cameroon.s official cotton production - which is dominated by low-yield small-scale farming - has decreased by almost $60 \%$ since its peak in 2004 . As presented in figure5.

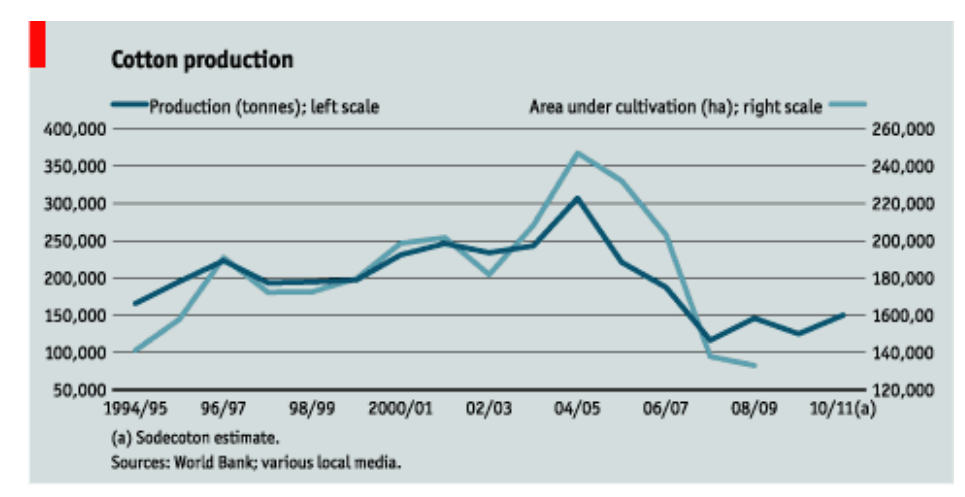

Source: EIU Digital Solutions, T. E. I. U., 2011 
Figure 5: Cotton Production in Cameroon from 1994- 2012

\section{The cotton belt of Cameroon}

The cotton belt covers the Northern part of Cameroon and includes three provinces: North, Extreme-North, and a small part of Adamaoua. The cotton belt population (3.6 million) represents one quarter of the country.s total. It is the poorest part of the country, with a high

level of illiteracy and the recurrent risk of food deficit due to climatic hazards. The region and its inhabitants are largely governed by a traditional feudal power structure manifested in tribal chieftains called lamidé, who control most social and economic activities.

The Northern part of the cotton belt (Extreme-North Province) is the primary historic growing zone where cotton was first introduced and developed, but represents less than one-third of total production. The zone is overpopulated, land pressure is high, and climatic conditions are less favorable than in the southern section of the cotton belt. Average rainfall hovers around $700 \mathrm{~mm}$ yearly so the province is subject to a high risk of drought, especially at the beginning of the planting season. In the southern section of the belt (North and Adamaoua Provinces), rainfall is higher (around 1200mm yearly), so the risk of drought more limited, and land pressure lower. Consequently, there is higher soil fertility, higher yields, and larger farm sizes; more than two-thirds of the cotton produced comes from these two provinces. The potential for development is concentrated in this southern belt and this development has been stimulated by the migration of farmers from the Extreme-North. Nevertheless, large swaths of the southern belt have been designated national parks in which it is forbidden to fall trees and clear land; much of the remaining land is reserved for livestock, with which agriculture is often in competition.

The cotton belt is effectively isolated from major transport routes with very difficult links to the capital and to the main port of Douala. Bales are transported on trucks from the ginneries to the railroad terminal Ngoundere where they are sent on to Douala. Both roads and railroads are in poor condition and result in delays and extra costs.

The soil conditions vary locally, but tend everywhere to be on the decline because of an inappropriate land tenure system perpetuated by the lamidé chieftains (farmers have usually no secure ownership on the land they cultivate), high land pressure, increasing cultivation on marginal and fragile lands, erosion, and inappropriate techniques for maintaining soil fertility as presented in figure 6 .

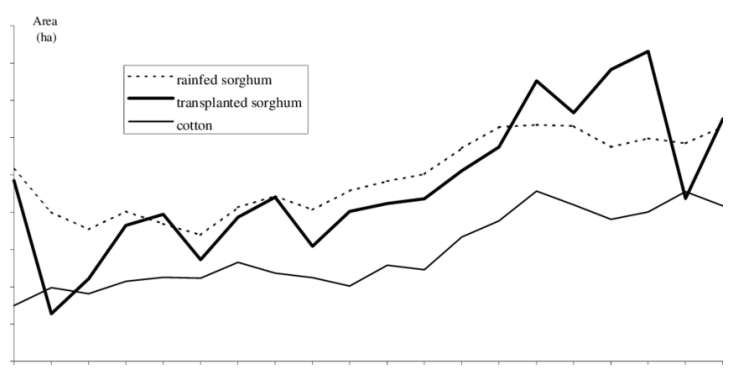

Source: Index Mundi, n.d.

Figure 6: Evolution of the main Crops in the Cotton Belt of Cameroon

\section{Methodology and Theoretical Framework}

\section{Theoretical Framework}

Production response studies owe much to Nerlove's seminal study of US farmers .production responsiveness in 1958. His model explains farmers. reaction based on price expectations and area adjustment, and proves that US farmers are sensitive to and react positively to prices.

In the later literature on agricultural production in developing countries (DCs), there is virtual unanimity that peasant production is also responsive to price incentives (Bond 1983, Eriksson 1993). On the other hand, several authors have shown how non-price factors impact on agricultural supply (Gbetibouo 1990, Opira 1997). These non-price factors include infrastructure, marketing, weather conditions and investments in research and development (R\&D).

The consensus arising from this debate is that both price and non-price factors have an impact on agricultural supply. The ensuing question, concerning how much this supply is respectively due to price and to non-price factors, is resolved once and for all by another consensus. As such, the ascendancy of either a group of factors or the other is dependent on the crop or the region under investigation (Ogbu and Gbetibouo 1990). 
For empirical evidence on agricultural supply, a linear programming or econometric approach can be used. The econometric approach is the most direct method for evaluating farmer response to incentives (Chhibber 1988a).Although the reference model is still that of Nerlove, it has been greatly modified in later studies that are distinguished on the basis of the scale of the analysis or the estimation approach. Studies that reveal the role of non-price factors are included in these two approaches.

The scale of analysis allows for distinguishing between microeconomic and aggregate supply studies. In the first case, analysis deals with a particular crop while in the second studies the agricultural sector as a whole. Using an aggregate approach, Azam et al (1990) show that shortage is a significant factor in explaining the supply of tradable crops. Using a microeconomic approach, Limbu (1997) demonstrates that there is a mixed impact of price and non-price factors in influencing cotton textile production changes in Tanzania. Contrary to these authors, Kagira (1996) combines the two approaches in estimating agricultural supply in Kenya, revealing prices, government incentives and rainfall as relevant factors.

A number of supply response studies have shown interest in the African cotton sector. Uma Lele et al. (1990) analyse performances between Anglophone and Francophone African countries and reveal that, despite the pertinent price rates, differences do arise rather from institutional measures. This study confirms the results of Mesru /Cirad (1989), which shows that management structures, initiated since the colonial period by CFDT are the main factor for the progress in cotton production in West and central Africa.

Baustista and Gehlhar (1994) examine the role of price incentives in the observed decline in cotton production in Egypt during the 1980s and in its apparent improvement in more recent years. It is shown that government interventions reduce price incentives in both short and long term and that sectoral price policy is more significant than macroeconomic factors in modifying cotton supply .Analyzing price effects on cotton production in Uganda, Opira (1998) shows that policy analyses on cotton production are useless if they exclude non-price factors. In evaluating the impact of government policies on the same crop in Tanzania, Dercon (1994) has shown that since producers. behavior is not uniform, no aggregate supply response exists for cotton.

In Cameroon, there are few studies that are cotton-based although this crop is included in sectoral studies. As such, Amin (1996) evaluates the effects of exchange rate policy on agriculture and shows that this factor fluctuation reduces agricultural output. On the other hand, Ntangsi (1991) analyses the structural adjustment implications on agriculture and concludes that, in spite of many constraints linked to SAP, these effects have been largely positive. Tshibaha (1997) looks at the effects of domestic economic policies and external factors on export prices and their implications for output and income. He concludes that external factors most significantly affect growth in export products.

Uma Lele et al.(1990) have pointed out the positive effect of guidance on cotton performance. Elsewhere, Madi (1994) has assesses cotton production as an incremental function of price. Not only is this result contradictory, as portrayed by data see table3 (Appendix) ,but also price is the sole explanatory variable. The analysis of Madi (1994) is then partial and the present study, based on the following methodology aims at filling the gap.

\section{Methodology}

Before embarking on an econometric analysis of the cotton supply function, the potentially relevant price and non-price variables should be discussed.

\section{Explaining Cotton Production in Cameroon}

Cotton prices are likely to be important variables. This study assumes that an increase of production is motivated by the need to buy more consumer goods .As such, the cotton price (Pc) is deflated by the consumer price index (Askari and Cummings 1977). Since farmers do not know the cotton price at the moment of sowing, price expectations rather than actual prices are the relevant explanatory variables. The previous price is included in the model as a proxy for this expected price: (pc/CPI)t-1 . In general, supply is an incremental function price.

Farmers in general also grow crops other than cotton, and the relative prices of competing crops could potentially explain changes in the production of Cotton. Farming systems analysis has suggested that millet is the most important competing crop: (Pmt/Pct). An increase in the ratio promotes millet production at the expense of cotton. Therefore, a negative relationship is expected.

Input prices for seed and fertilizers, commonly included in agricultural supply function, are excluded here. The reason is that seed and fertilizers are distributed on credit. Since it seems that farmers rarely pay back the loans and no data are available on the rate of reimbursement, it is appropriate to exclude them from the analysis.

On the other hand, some non-price variables seem very important in cotton production. Weather conditions constitute a crucial factor since cotton production is rainfed in Cameroon. The aridity index (W) already used by kagira (1996) and Limbu (1997) is used as a proxy for weather conditions. Depending on rainfall and temperature, it is computed as follows:

$$
\mathrm{w}_{\mathrm{jt}}=\frac{\text { average annual rainfall (millimetres })}{\text { average monthly temperature }(\text { centigrades })+10}
$$


Another assumption is that farmer is both a consumer and a producer and the production activity aims at providing income to ensure consumption expenses. In the area concerned, cotton is both the main trading crop and source of income for farmers, and for current consumption, the available funds come from lagged cotton sales: (Rci(t-1)). Thus, in relation to consumption needs, this income can induce the farmer to produce more or less cotton. Consequently, either a positive or negative relationship is expected.

Studies of the cotton sector in Cameroon have shown that the density of population changes among growing areas. Since a rise in population density reduces land availability and particularly that reserved for agriculture, this variable (DPj) can explain difference of performance among farmers as regards growing area.

Finally, it is assumed that the number of man-hour available per unit of area cultivated (MHit) can differentiate performance between farmers since labour is family-based in the area. The higher the family size the more man-hours are available for agriculture. Given the law of diminishing returns, the expected sign could either be positive or negative.

\section{The Model}

Based on previously developed models on supply in DCs and the potentially relevant variables presented below, the cotton supply function can be expressed as follows:

$$
Q c i t=f[(P c / C P i) t-p, P m t / P c, P f / P c, D P j t, R c i(t-j), r j i, \text { MHip ,Uit }] \quad \text { (1) }
$$

Where:

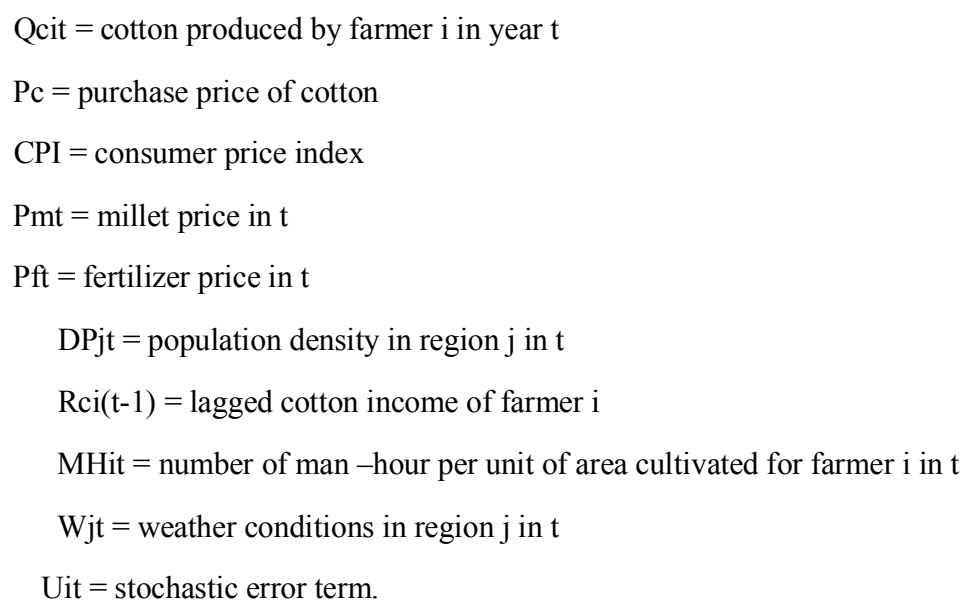

For data collection, there are four major sources used. The first is SODECOTON, which holds personalized technical information on cotton producers. This company handled about 310,000 producers of cotton in the 1998/99 season. Each year, it produces a technical information sheet for each farmer summarizing the farmer's production structure and costs. Data collected from these sheets are cotton production (QCit), area cultivated (Scit), cotton income ( RCit), farming system ,input prices, localization of farmers and cotton purchase prices to farmers (pc).

The second source is the farmers themselves by direct interview in order to verify and complete the previous source. Data on the family size have been collected in this way. Data on population (DPjt), weather conditions (Wjt) and consumer price indexes (CPI) are collected at the Department of statistics and National Accounting. The last source is the Ministry of Agriculture for information on agricultural sectoral policies in general and the cotton sector in particular.

\section{Empirical Estimates}

A panel data approach has been chosen for empirical estimates for the following reasons. First, the availability of a large number of data points increases the degrees of freedom and reduces co-linearity among explanatory variables second; panel data analysis allows carrying out both cross-sectional and time-series estimates based on the same body of data. Finally, it can allow a deeper understanding of cotton producers. behavior through the individual and temporal dimensions of the results (Koutsoyanis 1977, Dormont 1989, Dessus 1996). The choice of the model as well as of the estimator is Hausman`s (1978) specification tests.

\section{Sampling Procedure}

Since 1992, the number of farmers increased by an average by 6.8 percent annum, reaching 310000 in 1999 (SODECOTON 1999). A selection of 200 farmers, using ploughing system and cotton-cultivating area as criteria, was made from regular producers in the period 1992 to 1998. Some 76 per cent of farmers in the sample practiced HPS in 1992 and 24 per cent MPS .On the other hand, 60 per cent of using a sample quota choice and these percentages, the sample has been elaborated as presented in Table 3. 
Table 3: Sampling Structure

\begin{tabular}{lllll}
\hline & R1 & R2 & Share & Size \\
\hline HPS & 91 & 61 & 76 & 152 \\
\hline MPS & 29 & 19 & 24 & 48 \\
\hline Share & 60 & 40 & 1 & - \\
\hline Size & 120 & 80 & - & 200 \\
\hline
\end{tabular}

Source: author's calculations.

This table shows that among the selected 200 farmers, 120 leave in the North Province. Within these, 91 practice HPS and 29 MPS. Among the remaining 80 farmers in the Far North province, 61 are HPS-based while 19 practice MPS. The statistical description of this sample is presented in Table 4.

Table 4: Statistical Description of Variables

\begin{tabular}{llcll}
\hline Variables & Mean & $\begin{array}{c}\text { Standard } \\
\text { Deviation }\end{array}$ & Minimum & Maximum \\
\hline $\mathbf{Q C}_{\mathbf{i t}}$ & 222.732 & 174.948 & 12.000 & 1300 \\
\hline $\mathbf{R c}_{\mathbf{i t}}$ & 300.590 & 259.512 & 20.892 & 1793 \\
\hline $\mathbf{D P}_{\mathbf{i t}}$ & 38.148 & 26.696 & 15.500 & 75 \\
\hline $\mathbf{V}_{\mathbf{j}}$ & 20.492 & 1.519 & 17.500 & 23.700 \\
\hline $\mathbf{M H}$ & 1.908 & .921 & .350 & 9.600 \\
\hline $\mathbf{( P c / C P I})_{\mathbf{t}}$ & 101.772 & 9.963 & 84.400 & 113.865 \\
\hline $\mathbf{( P f} / \mathbf{P c})_{\mathbf{t}}$ & 118.853 & 23.302 & 85.870 & 143.102 \\
\hline $\mathbf{( P m} / \mathbf{P c})_{\mathbf{t}}$ & 80.468 & 16.259 & 66.053 & 108.757 \\
\hline
\end{tabular}

Source: author's calculations.

\section{Results of Regressions}

This Section Presents and discusses the findings of the empirical analysis. Before running the regressions, it was found out which variables are correlated which each other. This exercise suggested that cotton price is correlated with that of fertilizers and fertilizers with millet.To examine this problem, step wise regressions were attempted whereby one regressor was included after the other .Results with regard to the aggregate model (Table 4) are discussed, followed by those from sub-samples dependent on cottoncultivating areas and ploughing system models . Since variables in all regressions are expressed in logs, coefficients are directly interpreted as elasticities. As presented in table 5.

Table 5: Regression Results for the Aggregate Model (t-statistics in parentheses)

\begin{tabular}{|c|c|c|c|}
\hline Variables & Plain OLS & FEM & REM \\
\hline $\mathbf{R c}_{\mathrm{it-1}}$ & $\begin{array}{l}.686 \quad .683 \\
(36.209)(36.093)\end{array}$ & $\begin{array}{l}.075 \quad .075 \\
(2.776)(2.791)\end{array}$ & $\begin{array}{l}.355 \quad .350 \\
(16.334)(16.230)\end{array}$ \\
\hline$D P_{t}$ & $\begin{array}{ll}-.444 & -.379 \\
(-.904) & (-.773)\end{array}$ & $\begin{array}{l}-.029-.029 \\
(-3.001)(-3.018)\end{array}$ & $\begin{array}{ll}-.471 & -.435 \\
(-.597) & (-.550)\end{array}$ \\
\hline $\mathbf{W}_{\mathrm{t}}$ & $\begin{array}{ll}-.013 & -.986 \\
(-1.327) & (-1.051)\end{array}$ & $\begin{array}{l}-.025 \quad-.025 \\
(-2.964)(-3.011)\end{array}$ & $\begin{array}{ll}-.010 & -.959 \\
(-1.579) & (-1.400)\end{array}$ \\
\hline $\mathbf{M H}_{\text {it }}$ & $\begin{array}{l}-.476-.476 \\
(-16.815)(-16.779)\end{array}$ & $\begin{array}{ll}-.792 & -.792 \\
(-24.481) & (-24.508)\end{array}$ & $\begin{array}{ll}-.715 & -.715 \\
(-25.039)(-25.038)\end{array}$ \\
\hline $\mathbf{P c}_{\mathrm{t}-1}$ & $\begin{array}{l}-.732 \quad- \\
(-2.083)\end{array}$ & $\begin{array}{l}-.029- \\
(-.114)\end{array}$ & $\begin{array}{l}-.311{ }^{-} \\
(-1.205)\end{array}$ \\
\hline$(\mathbf{P f} / \mathbf{P c})_{t}$ & $\begin{array}{ll}.506 & -.889 \\
(-2.437) & (-9.267)\end{array}$ & $\begin{array}{l}.305 \quad .289 \\
(1.871)(3.270)\end{array}$ & $\begin{array}{ll}.136 & -.293 \\
(-.897) & (-3.880)\end{array}$ \\
\hline$(\mathbf{P m} / \mathbf{P c})_{\mathrm{t}}$ & $\begin{array}{l}.215 \quad .312 \\
(2.098)(3.420)\end{array}$ & $\begin{array}{l}.358 .361 \\
(4.376)(4.729)\end{array}$ & $\begin{array}{l}.238 .279 \\
(3.182)(4.191)\end{array}$ \\
\hline $\mathrm{C}_{\mathrm{it}}$ & $\begin{array}{ll}6.841 & 4.805 \\
(6.406) & (11.138)\end{array}$ & $\begin{array}{l}(4.376)(4.729) \\
-\quad-\end{array}$ & $\begin{array}{ll}4.918 & (4.046) \\
(6.242) & (12.747)\end{array}$ \\
\hline A. $\mathrm{R}^{2}$ & $\begin{array}{ll}.68 & .68 \\
\end{array}$ & $\begin{array}{ll}.83 & .83 \\
\end{array}$ & $.74 \quad .74$ \\
\hline
\end{tabular}

Source: author's calculations.

As can be seen in the table, there is no significant difference between results generated by plain OLS model and those by REM. But since the Hausman test rejects the null hypothesis, the FEM is favoured. This preferred FEM suggest that a specific fixed effect differentiates farmers. behavior.

As regards results, all variables significantly affect cotton supply except cotton price. Millet price has an unexpected result since cotton production increases when this variable goes up. The explanation could be that farmers consider millet not only as a food crop but also as cash crop in diversifying their income sources. This result, also found in Tanzania (Limbu 1997), is strengthened by the income elasticity sign. In fact, it was assumed that income positively affects cotton supply only if its level does not ensure current 
consumption expenses. Since this sign was positive, one can suggest that farmers need diversifying income sources, and millet is prospective in this regard. The elasticity sign of fertilizer price was also unexpected. The twin explanation could be that since fertilizer are crucial in cotton -cultivating, farmers use them whatever their price (Madi 1994); and secondly, since these fertilizers are sold on credit, farmers have to produce more cotton in an attempt to return the increasing loan as the fertilizer price increases. As such, cotton production increases as fertilizer price goes up.

Finally, regression results have shown that production reduction is largely caused by an increase in the number of man-hours, and not, for example, by a decreased cotton price. Indeed, cotton supply significantly decreased as the number of man-hours went up .This result seems to outline that an unoccupied labour force exists in cotton-growing areas. As such, the cost of man-hours is higher than its contribution to cotton production.

In an attempt to confirm assumptions according to which cotton-cultivating areas and ploughing systems differentiate farmers. behavior, comparative analysis of aggregate and sub-sample models is now in order. The first general finding is that contrary to the aggregate model, the REM has been found favorably better for all sub-sample models. Regression results are therefore presented in table 4 these preferred models only. The comparative effects of aggregate and growing area models are discussed, followed by that of the same aggregate model relative to the ploughing systems used. AS presented in table 6 .

Table 6: Regression Results for the sub-sample Models (T-statistics in parenthesis)

\begin{tabular}{|c|c|c|c|}
\hline Variables & Zonal Models & Ploughing System & Models \\
\hline & North Far North & HPS & MPS \\
\hline$R c_{i t-1}$ & $\begin{array}{lc}.400 & .285 \\
(14.426) & (8.093)\end{array}$ & $\begin{array}{l}.354 \\
(14.893)\end{array}$ & $\begin{array}{l}.196 \\
(3.530)\end{array}$ \\
\hline $\mathbf{D P}_{\mathbf{t}}$ & $\begin{array}{ll}.646 & (.473) \\
(.222) & (-.329)\end{array}$ & $\begin{array}{l}.017 \\
(.531)\end{array}$ & $\begin{array}{l}-.123 \\
(-2.093)\end{array}$ \\
\hline $\mathbf{W}_{\mathbf{t}}$ & $\begin{array}{lc}-1.602 & -.329 \\
(-1.931) & (-1.891) \\
\end{array}$ & $\begin{array}{l}.062 \\
(.406)\end{array}$ & $\begin{array}{l}-.976 \\
(-3.226)\end{array}$ \\
\hline $\mathbf{M H}_{\text {it }}$ & $\begin{array}{ll}-.730 & -.698 \\
(-19.721) & (-15.480) \\
\end{array}$ & $\begin{array}{c}-.721 \\
(-22.066)\end{array}$ & $\begin{array}{l}-.645 \\
(-11.112)\end{array}$ \\
\hline$(\mathbf{P f} / \mathbf{P c})_{t}$ & $\begin{array}{lr}-.605 & -.352 \\
(-1.345) & (-2.892)\end{array}$ & $\begin{array}{l}-.280 \\
(-3.350)\end{array}$ & $\begin{array}{l}-.080 \\
(-.469)\end{array}$ \\
\hline$(\mathbf{P m} / \mathbf{P c})_{t}$ & $\begin{array}{lc}.471 & .261 \\
(1.654) & (2.316) \\
\end{array}$ & $\begin{array}{c}.306 \\
(4.128)\end{array}$ & $\begin{array}{l}.148 \\
(1.016)\end{array}$ \\
\hline $\mathrm{C}_{\mathrm{it}}$ & $\begin{array}{ll}7.272 & 5.099 \\
(1.336) & (4.532) \\
\end{array}$ & $3.445(5.445)$ & $\begin{array}{l}7.295 \\
(5.937) \\
\end{array}$ \\
\hline A. $\mathbf{R}^{\mathbf{2}}$ & $.77 \quad .69$ & .76 & .52 \\
\hline
\end{tabular}

Source: author's calculation.

It has been shown for the aggregate model that all variables, except cotton price, affected cotton supply. This is not the case as regards regression results from cotton-cultivating areas. Contrary to the North province, where no prices were found relevant, that of fertilizers and millet significantly impacted on cotton supply in the Far North province. As can be see in Table 6, farmers significantly react to more variables in the Far North province than in the North province. As such, significant explanatory variables change from one growing area to another as well as from zonal models to the aggregate one. Therefore, farmers. behavior is not uniform and no aggregate supply response exists for cotton in Cameroon. Dercon (1994) found similar results in evaluating the impact of government policies on cotton production in Tanzania.

In comparing regression results between the aggregate and the ploughing system models, it has once more been shown that no aggregate supply response exists for cotton in Cameroon. As portrayed by the data in Table 3 millet and fertilizer prices that were relevant for the aggregate model are still relevant, but now for the HPS model only. On the other hand, and unlike the HPS model , weather conditions and population density affected cotton supply in both aggregate and MPS models . As such, the ploughing system is an indisputable criterion in defining differentiated policy incentives towards cotton production in Cameroon.

Another finding of the study is that cotton supply increases as income goes up but decreases as the number of man-hours per unit of area cultivated increases. Since this result is pertinent in both aggregate and sub-sample models, as can be seen from Table4.3, the income and the number of man-hours constitute the plinth variables of related government policy towards cotton production in general.

\section{Conclusions}

In an attempt to support government policy towards cotton production in Cameroon ,this research has provided empirical evidence showing how both price and non-price variables not only affected cotton supply but also differentiated farmers .behavior.

Using a panel data approach, the study has mainly demonstrated that no aggregate production response exists for cotton since farmers. behavior is not uniform. In fact, a striking difference has been noted between the aggregate and the various sub-sample models towards variables that significantly impacted on cotton production. While all variables, except cotton price, were found relevant for 
the aggregate model, some of these were insignificant either in one growing area and not in another or in one ploughing system and not in another.

The main policy implication of such a result is that, since no aggregate production response exists for cotton, government policy towards cotton production might be differentiated dependent of target .Therefore, it has been demonstrated that growing areas and ploughing systems constituted pertinent criteria in defining these differentiated and supporting policies towards cotton production in Cameroon. As regards growing areas, for example, in addition to income and number of man-hours, government policy has to pay attention to input and alternative crop prices in improving cotton production in the far North province.

Econometric analysis has also shown that the income and number of man-hours available per unit of area cultivated significantly impacted on cotton production in all areas. Linking the negative sign of elasticity of the number of man-hours to the law of diminishing returns, it has been assumed that unoccupied labour exists in cotton-growing areas. To resolve such a problem, ways should be sought to ensure that farmers increase the area under cotton cultivation in an attempt to exploit efficiently the available labour force. This solution is feasible since cotton production is not constrained by available land as portrayed by the insignificance of population density in the sub-sample models.

\section{Acknowledgement}

I would like to express special thanks and appreciation to my Professor Cheng Hua for her tremendous mentorship and encouragement during this research.

\section{References}

Amin, A.A,.(1996). The Effects of Exchange Rate Policy on Cameroon's Agricultural Competitiveness, AERC Research Paper No.42, Nairobi.

Askari, H and J.T. Cummings, (1977). Estimating Agricultural Supply Response with the Nerlove Model: A Survey ., International Economic Review, vol. 18, No. 2, pp.257-92.

Azam, J.P et J.C .Barthelemyer Morrison, (1991). L'Offre de Culture Commerciales en Economie de Penuries. Revue d.Economie politique, vol. 42, No, 3, pp.553-73.

Bautista, R. M., \& Gehlhar, C. G. (1994). Price competitiveness and variability in Egyptian cotton: Effects of sectoral and economywide policies. Washington, DC: IFPRI. mimeo.

Binswanger, H., (1989). The police Response of Agriculture. Proceedings of the World Bank

Blandford, S,. D. Friedman, s. Lynch, N. Mukherjee, and D.E. Sahn, (1995). 'Oil Boom and Bust: The Harsh Realities of Adjustment in Cameroon. In: D.E. Sahn, ed, Adjusting to policy Failure in African Economies, Cornell: Cornell : Cornell University Press.

Bond, M.E,. (1983). Agricultural Responses to prices in sub-Saharan African Countries. IMF Staff papers, vol. 30 , No 4.

Business In Cameroon. (2019, March 5). Cameroon: Raw cotton export grew by 23\% in 2018. Retrieved July 10, 2019, from https://www.businessincameroon.com/agriculture/0503-8911-cameroon-raw-cotton-export-grew-by-23-in-2018.

Cameroon CM: Nominal Effective Exchange Rate Index: From INS. (2019, September 23). Cameroon: CM: Nominal Effective Exchange Rate Index: From INS: Economic Indicators: CEIC. Retrieved September 28, 2019, from https://www.ceicdata.com/en/cameroon/nominal-and-real-effective-exchange-rate-index-annual/cm-nominal-effectiveexchange-rate-index-from-ins.

Chhibber, A,. (1988a), Croissance de la production Agricole: Incidence des prix et des autres Fracteurs. Finances et developmment, Jun, pp.44-7.

Chhibber, A,. (1988b), The Aggregate Supply Response: A survey, In: S, Commander, ed,.

CIRAD (1994), Modeliser les comportments des Menages Agricoles dans le cadre de politiques de reforme Economique, Paris : CIRAD/ URPA.

Colman,D,. (1983), A Review of the arts of supply Response Analysis,. Review of Marketing and Agricultural Economics,vol . 51, No.3.

Dercon, S., (1994), Peasant Supply Response and Macroeconomics Policies : Cotton Tanzania,.

Dessus, S,. (1996), Introduction a l.economotrie des Donnees de panel ,Document Special No. 5, RPI, Dakar, Senegal.

Dormont, B,. (1989), Introduction a l.econometrie de panel: Theorie et Application a des Echantillons d .Entreprises, Paris: Edition du CNRS.

Douya, E,. (1998).Analyse de la competitivite de la filiere cotton au Cameroun, Rapport definitive presente au RPE,. Dakar, Senegal.

EIU Digital Solutions, T. E. I. U. (2011, May 4). Black market activity flourishes in the cotton sector. Retrieved July 10, 2019, from http://country.eiu.com/article.aspx?articleid=788066463\&Country=Cameroon\&topic=Economy\&subtopic=C_7.

Erisksson, G., (1993), Peasants: Response to price Incentives in Tanzania: A theoretical and Empirical Investigation, Scandinavian Institute of African Studies. Uppsala, Research Report No.91.

FAO, (1995). Analyse de 1. Impact de la Devaluation du FCFA sur la production Agricole et la securite Alimentaire et proposition d. action, Rapport Technique,TCP/CMR/3452, Rome: FAO. 
FAO, Chambre d.Agriculture, Debazou Y. (2004), Vers un mécanisme national d.action collective des agriculteurs paysans du Cameroun.

Gbetnkom, D, and A.S. Khan, (1999) .Determinants of traditional and Non-traditional Agricultural Exports: The case of Cameroon, Interim Report, Nairobi: AERC.

Hausman, J.A. (1978). Specification Tests in Econometrics. Econometrical, vol. 46, pp. 1251-71.

Hsiao, C,. (1992).Analysis of panel Data, Econometric Society Monographs, Cambridge : Cambridge : Cambridge University Press

Index Mundi. (n.d.). Cameroon Cotton Production by Year. Retrieved September 28, 2019, from https://www.indexmundi.com/agriculture/?country=cm\&commodity=cotton\&graph=production.

Junankar, PN ,. (1989). The response of peasant Farmers to price Incentives: The Use and Misuse of profit Functions,. Journal of Development Studies, Vol. 25 No.2, pp. 169-82.

Kagira, B.M. Agricultural Output Response to output and Input Process: Tbe Case of Kenya,

Kloboukoff, P,. B. Lesluyes et J.C Le Goff, (1995). La competitivite de la Filiere Textile en Afrique Subsabarienne, Paris: Ministere de la cooperation.

Koutosoyanis, A,. (1977), Theory of Econometrics, 2nd edn, Hong Kong: Macmillan.

Lau,L,.J. and P, Yotopoulos (1971). A Test of Relative Efficiency and Application of Indian

Limbu, F ,. (1997), Response of cotton supply to price and Non-price incentives in Tanzania, AERC, Final Report, Nairobi.

Madi, A ,. (1994),.La politique des prix et la Dynamique du systeme Productif dans la Zone cotoniere au Cameroon .These, Montpellier (France).

Mathieu, Bertrand \& Gautier, Denis \& Fotsing, Eric. (2019). The Recent Extension of Muskwari Sorghums in Northern Cameroon.

MBENGONO, C. (2018, December 21). Cameroon: Insufficient cotton processing. Retrieved July 10, 2019, from https://237cameroun.online/en/economy/cameroon-insufficient-cotton-processing.

République du Cameroun, (1990), Nouvelle Politique Agricole.

SODECOTON, (1999), Rapport d'activites 1998/1999, Garoua, Cameroon Structural Adjustment and Agriculture: Theory and Practice in Africa and Latin America, Oxford: lames Curry Publishers, pp.55-68.

Townsend, T. (2018, July 19). Cotton in the World Economy. Retrieved July 10, 2019, from http://cottonanalytics.com/2018/07/.

Uma, L,. N. Van Walle and M. Gbetibouo, (1990), Cotton in Africa: An Analysis of Differences in performance, Media Discussion Paper No. 7, Washington, DC: World Bank. 